\title{
Incentive Effects of Granting Equity-Based Payment on Reducing Top Executive Turnover
}

\author{
Zuriadah Ismail $^{1}$, Noor Lela Ahmad ${ }^{1}$, Norlia Mat Norwani ${ }^{1} \&$ Mohd Nazir bin Md Zabit ${ }^{1}$ \\ ${ }^{1}$ Universiti Pendidikan Sultan Idris, Tanjung Malim, Perak, Malaysia \\ Correspondence: Zuriadah Ismail, Universiti Pendidikan Sultan Idris, Tanjung Malim, Perak, Malaysia. E-mail: \\ zuriadah@fpe.upsi.edu.my
}

Received: October 10, 2019

Accepted: November 5, 2019

Online Published: December 23, 2019

doi:10.5430/rwe.v10n5p157

URL: https://doi.org/10.5430/rwe.v10n5p157

\begin{abstract}
The main focus of the study is to examine the incentive effect of granting equity-based payments for reducing turnover among the executives. In specific, the study was guided on determining the influencing effects of managerial ownership and equity-based payment may reduce executive turnover among the Malaysian Listed companies. From the analysis, the main finding shows that firms with equity-based programme with a presence of family control indicates that turnover is likely to be a lower. This implies that family ties play a significant role for removing of inefficient executives. And, where the family members are also served as the board members, the likelihood to shield from being removed is consistent with the management entrenchment hypothesis. Then, extended examination results for the mix pay components of cash and equity reveal the turnover is found to produce less incentive for executives to stay in the firm. The result implies that executives are willing to lose their equity benefits from unexercised value of shares equity and nd the firms fail to restrain executives' departure as the findings documented in past studies.
\end{abstract}

Keywords: equity-based payment, executive turnover

\section{Introduction}

Based on history, it reveals clear indication that family founding firm has a significant element in the corporate establishment. This is because a family-based business has been established for a long time ago and has proven with a good firm performance. Examination on past literature,such as Abdul Rahman (2006) indicates that the main nature of Malaysia listed firms were owned by family business, although the history proved that since independence most of the Malaysian firms were controlled by foreign investors and the government. More ddiscussion on family business characteristics in Malaysia by Mosbah, Serief and Kalsom Abd Wahab (2017) found that several indicators could be used for their identification including business contributions to GDPs, firm size, business owned by ethnic and preference to follow culture and management style of the business founder. And the family culture may have a significant impact on family founding firm performance where the successful story of family founding firms find the roles of participation and ethnic networks governing the entrepreneurial practice. However, the finding has been argued by Wee, Mohammed Dahlan and Hasliza Abdul Halim (2015) which explained the functions of family business that are purely based on cultural factors need for a thorough examination (Hussain et al., 2018).

A study of Claessens, Djankov and Lang (2000) use a sample on the nine East Asian countries including Malaysia found that Malaysia has the third highest in regard of ownership concentration from control from $57.7 \%$ to $67.2 \%$. And the "Look East Policy" has changed the capital market structure by attracted more investors to enter joint ventures with local firms (Haslindar Ibrahim and Fazilah Abdul Samad, 2010). The trend is consistent with a current report published by the Credit Suisse Research Institute (CSRI) through the Edge Market dated on $30^{\text {th }}$ October 2017. The report highlights that the Malaysian family-based firms were ranked at seventh globally in terms of number of family-owned businesses. Based on the report, the Malaysian family business firms are outperforming than their peers in every sector regardless their size. And the Malaysia's Press Metal is among the top 50 family-owned firms globally with market capitalisation above USD $\$ 2$ billion in terms of average revenue growth since 2014. In 2018, the report by CSRI has illustrated that family-owned businesses demonstrate stronger revenue growth, higher margins, better cash flow returns and lower gearing compared with non-family-owned business. Malaysia was ranked in third place with three companies on the top 30 listing firms. 
Then, Gomez (2004) studied on a family founding firms in an Asian context, which relate to ethnic-based firms and the main result shows that Chinese ethic family-based firms have a significant contribution to the development of the Asian economic growth. The emergence of Chinese family firms in Malaysia which was commenced due to a history of intra-ethnic business partnership. The result is slightly consistent with Mohd Sehat and Abdul Rahman (2005) which was determined on the ownership concentration from the perspective of direct shareholdings for the 100 Malaysian listed firms. The finding shows that more than 50\% of the companies have owned and controlled more than $57 \%$ of shares by the blockholders. This highlights that the nature of Malaysia firms were highly concentrated in its ownership and control. Another study by Haslindar Ibrahim and Fazilah Abdul Samad (2010) examined the 40 richest Malaysians firms which were dominated by family members according to various definitions of family ownership. They have compiled the significance of family firms in Malaysia in producing numbers of tycoons with their respective business field. And a study by Nor Afza Amran and Ayoid Che Ahmad (2013) concluded that high concentrated ownership structure in Malaysia family founding firms may be influenced by the families' business style, culture, race and laws imposition with all listed companies need to issue at least $25 \%$ of the shares to the public. Therefore the remaining shares can still be owned by family members. Further results reveal that managerial ownership is significantly relates to market performance indicator of Tobin's Q which suggesting that insider ownerships may enhance the firm performance due to re-alignment between internal and external interests, thereby reducte in conflict of interests among the shareholders. Then, the executive with a greater control and large shareholdings are more concerned with their own self-interests than the interests of the shareholders at large. Mosbah, Serief and Kalsom Abd Wahab (2017) extend their the link with performance among the family business, they found that through financial indictors using a Tobin $Q$ ratio reported the performance of family firms may be significantly influenced by their culture practices.

The potential agency problem in a family-based firm was given attention to study of ownership issues in the work of La Porta, De-Silanes and Shleifer (1999) and Claessens, Djankov and Lang (2000). Both studies have found that most of listed firms which are controlled by family members and it has been determined for shaping the Malaysian corporate environment and culture since years ago. Where the case of high involvement of family members to serve as shareholders and actively engage in the board of directors (BODs) making the problem of agency more severe. According to Zahirudin and Fauziah (2012); Mulyani, Singh and Mishra (2016) indicate that greater stakes by members of family establish a conflict between majority and minority shareholders relationship. Then, the conflict for both shareholders would significantly appear when the family members also hold position as executives exploit their position to gain self interest in any corporate decision. This places a pressure for minority shareholders to control the executive's action. The notion is consistent in study findings by Weisbach (1988), Denis, Denis and Sarin (1997) and Huson, Parrino and Starks (2001). All studies found that in a family firm with higher agency problem would experience difficulty to remove any underperforming executive among the family members. This implies to a low executive turnover rate in family founding firms. As Cheung, Rau and Stouraitis (2006) have found that if a firm with family domination in shareholdings there is a likely to have an incentive for agency conflict. In the same context of family domination executives, also misuse of their legal right as shareholder to mandate them as firm's management. However, with largely dependent on the existing legal system is to monitor the family executive's behaviour which is not adequate to counter their extreme cases (Sokół and Słupińska, 2019).

Other than, a trust between family members could be served as a mechanism to alleviate at least a partially the problem between executives and minority shareholders (Rachpradit, Tang and Khang, 2012). In past studies show that an initiative of invitation executive to become part of the owner produce contrasting result to firm that are managed by independent executives. For example, Chen, Cheng and Dai (2013) which focus a study on the executive turnover and firm performance, they found that family firms which are leading by non-family executives have reported a high turnover rate than firm managed by family members (Prakash and Garg, 2019). Perhaps, family executive members are more concern about firm performance because they are holding positions with having significant investment value. Given the power to family executives, however, it could lead to a potential of family entrenchment sensitivity. Since family- domination executive has a significant influence due to its concentrated ownership and involvement in firm's management, this produces to the potential for family members to pursue their own interests at the expenses of shareholders. As a consequence, granting equity-based payment in family founding firms has become a corner-stone for addressing the issue of agency problem in Malaysia which is well documented in many literature (Claessens, Djankov and Lang, 2000; Haniffa and Hudaib, 2006; Senam, Akpan and Mboho, 2017).

Suggestion in literature that introduction of equity-based compensation plan could be dedicated for retaining the non-family executives (Kole, 1997 and Oyer and Schaefer, 2005). And, the effect is sligtly appear when the cost of executive turnover can be very high for termination. Therefore, firms with equity-based plan are commonly used to tie 
executive with performance of firm. Thus, the executive would accept the equity pays if it increases their earnings. This suggests for a positive relationship between the equity payments and firm value. However, if a firm performing poor usually the non-family executive is likely to leave the firm. This suggests for increasing turnover rate and the relationship between the use of equity-based plan and firm value is a negative association (Warner, Watts and Wruck, 1988; Weisbach, 1988 and Dennis et al., 1997). In Malaysia context of implementing equity plan, the application is heavily granted at the non-executive employee level. Thus, the sensitivity of compensation pay to executive turnover was expected to be quite low in a family founding firm (Zuriadah, Nurhanie, Emelda and Dockery, 2016). This is consistent with reasons of executives in family business have a control over firm, if they are not satisfied with the benefits they receive the likelihood is that they may leave the firm voluntarily is higher. Therefore, examination on the link between equity-pay could decrease a turnover rate in Malaysian firms would enable for conclusion about the roles of alleviating effect on unexpected executive turnovers in firms with family domination executives.

\section{Hypotheses Development for Executive Turnover}

The decision to remove for ineffective executive would be seemed to be determined by on the ownership structure. This is to support with principle under the agency theory which posits a conflict of interests could be aligned through separating executive power and ownership. In this regard, the adoption of equity pays through increasing stakes of executives as firm minority shareholders; the likelihood to reduce potential conflict with majority shareholders is higher. This is slightly equal to nature of shareholdings in Malaysian listed firms that are largely dominated by the family members. Gibson (2003) reveals that there is a tend they are to be actively involved in managing business and served on the firm's boards. The extents of past results in several studies produce contrasting result about the agreement between involvement family members and non-family members in the firm management on turnover. For example, Lausten (2002) and Volpin (2002) studied on turnover rate by executives on Danish and Italian firms; found that family-domination firm decreases the number of executive turnover. The observed effect of family-based firms on the executive turnover should be a negative association because of strong family-management ties. Another sight of story, as seen on the non-family controlled firms which noted that the effects of executive turnover are weaker which reveal with a low sensitivity towards firm performance (Tsai, Hung, Kuo \& Kuo, 2006). This shows a clear signal that the business with non-family-domination to be less effective in terms monitoring the turnover rate.

Discussion to same issue on executive turnover, Denis et.al (1997) suggest a lower event of executive turnover, where independent directors play an important role for monitoring management with owing to the high stakes inside the firm. This leads the outcome to be less sensitive to firm value as the controlling effects are significantly observed with higher control. Therefore, executive's decision to leave the firms would be controlled by the cost of benefits to be forgone by them. If a family ownership has an opposite direction on executive turnover, it is likely by granting equity plan to family members would increase their stakes in the firm, but also reveal bad news to existing shareholders. This effect is particularly observable if the boards plan to appoint outside candidates to lead the CEO position. Suchard, Singh \& Barr (2001) conducted an analysis for the association between the CEO's monitoring by inside and outside directors and they found that non-executive directors are more likely to monitor the family executive. While, Shen and Canella (2002) examined the effect of CEO dismissal on firm performance, and followed by inside candidate selection. They result shows a positive association effect if it is inside succession. Iqbal and French (2007) studied on the managerial stakes for 260 financial distress firms and found that the less ownership executives have, there are more likely to be removed rather than their higher ownership counterparts. Thus, a strategy for shares acquisition during financial difficulty could be a signal of increasing shareholding activity and a way for executive to avoid being removed. Lu, Reising \& Stohs (2007) noted that high shareholding executives would exercise greater power and shielding themselves from termination in a poor performing firm. The negative effect could be reduced if equity-based plans are properly designed by incurring turnover cost on the executives' departure (Balsam, Gifford \& Kim, 2007; Marshal, 2017). And for firm with equity plan, the cost of leaving may be defer a in a few years following the granting date. Balsam and Miharjo (2007) noted in study finding which showing that the low turnover rates within firms are usually observed during the vesting period. Therefore, high stakes in the firm by executives in a family-owned firm to be less affected by turnover when equity plans are granted. Thus, it is hypothesized that executive turnover is likely lower in the firm with high family ownership and control.

\section{Research Methodology and Data}

\subsection{Data Selection}

As the main objective of the study is to examine executive turnover, the data for 173 Malaysia firms with equity compensation plan that are targeted at executive levels from 2013 and 2017 were chosen. For equity plan information, it was retrieved annually from multiple sources including disclosure in company annual report and the company 
announcement section on stock exchange. These data have been used to identify all high level executives for each firm included in the sample. And, executive's age is adopted the cutting off point for division of turnover types between the forced and routine turnover. Under the old the company law (CA)1965, the official age of Malaysian director retirement is 70 years old (Section 129[1]) and an additional clause allows director above this age is to be re-appointment as a board member by passing a special resolution. This means a decision to be re-elected as a director must approve by $75 \%$ of shareholders (Section 129 [6], CA 1965). Thus, the study analysis of executive turnover could be enhanced by identifying whether individual executive left their position at the age of 70 as routine (retirement) and replacement by board members is treated as forced turnover. This is similar adoption by Goyal and Park (2002) who found that a significant association between executive age and turnover.

\subsection{Dependant Independent Variables}

Since the dependent variable for executive turnover is based on turnover types and the independent variables in the model estimation will employ managerial ownership structure and compensation pays to determine the likelihood of executive departure. And the two proxies were included to test the effect on executive turnover. Then, the variables were added in each model which includes managerial ownership and a dummy for family control. For definition of family controlled firm, including La Porta, De-Silanes and Shleifer (1999) classify the family gains power by exercising voting rights when it has at least $20 \%$ support and this value is sufficient for making sample decisions. While Anderson and Reeb (2003) associate the founding family firm if it is run by the family member, hence, a family-owned firm is identified based on family ties on the board. And alternative approach suggested by Maury (2006) based the family surname.

A dummy variable is created and added in each model equated to 1 if the family member occupies the board and 0 otherwise. Furthermore, include variables if the executive has stakes in the firm through equity-based payment (i.e. stock options) in family control firm could generate an advantage to determine whether the family-owned business has voted to eliminate their family members due to inefficiency or underperformance. Thus, Denis et. al. (1997) describe that managerial ownership could influence the executive turnover in a negative direction. This is partially suggests that stock option plans could be way to increase insider ownership, even the result is less sensitive to firm condition. Therefore, a dummy variable of 1 is used for top executives who have stakes in the firm and 0 otherwise.

\section{Study's Findings and Discussion}

The analysis for descriptive statistics show that there are about $10 \%$ of executive turnover events has occurred during the sampling period. And the percentage value is slightly consistent with two studies in the US which reported at $13 \%$ and 10\% respectively (Coughlan and Schmidt, 1985 and Mehran and Yermack, 1997; Orumwense, 2017). The result illustrated in Table 1 shows the sample selection firms based the board listing and its sectors classification as the majority of listed firms with equity plan provided for executives are from regulated market. And the event of executive turnover is largely dominated from industrial and trading services. Where the event of executive turnover is split across the firm performance, more than $75 \%$ of executive turnover have been experienced during a positive firm value which suggesting that firms enjoy healthy firm condition fails to guard for executive's decision to leave the firm.

Table 1. Firm data characteristics for executive turnover types

\begin{tabular}{|c|c|c|}
\hline & $\begin{array}{l}\text { Forced turnover } \\
(\%)\end{array}$ & $\begin{array}{c}\text { Routine turnover } \\
(\%)\end{array}$ \\
\hline \multicolumn{3}{|l|}{ Stock exchange } \\
\hline 1. Main Board market & 80 & 16 \\
\hline 2. Non-main Board market & 4 & 0.4 \\
\hline \multicolumn{3}{|l|}{ Business Sector Classification } \\
\hline 1. Construction & 8 & 2 \\
\hline 2. Consumer Product & 10 & 2 \\
\hline 3. Industrial Product & 25 & 5 \\
\hline 4. IPC & 1 & 0.1 \\
\hline 5. Plantation & 4 & 0.7 \\
\hline 6. Properties & 7 & 1.3 \\
\hline
\end{tabular}




\begin{tabular}{rlcc}
\hline 7. & Technology & 8 & 2 \\
\hline 8. & Trading and Services & 20 & 3 \\
\hline \multicolumn{2}{l}{ Firm Performance types } & & \\
\hline 1. & High performance & 64 & 13 \\
\hline 2. & Low performance & 20 & 3 \\
\hline
\end{tabular}

Then, the analysis was extended to examine the factors by which executives are likely to be influenced the turnover decision. Based on past studies, the variable of managerial ownership structure and compensation pays are determined to have an effect on turnover decision. A detailed summary of all variables used in the study is displayed in Table 2 and 3. According the mean value, executive turnover reveals no difference between family-controlled and non-family firms. While, for performance measures shows that using accounting predictor produces a positive value to decision of executive leaving the firm. When replacing to market-based indicators, the results reveal a contrast mean value for all samples. This suggests that executive turnover is likely to be reported higher which suggests that removal executives convey bad news to the market, even though the firm's decision to remove for an inefficient or underperformance executive. For result validation for hypothesis about poor corporate performance contribute higher turnover rate, the variable for negative operating income was analysed. And the positive value in mean confirmed the study conclusions that executive leaves during poor corporate performance.

Testing for variable of managerial stakes inside the firm, a similar percentage value was showing across the sample groups with indication of 59\% were controlled by non-family members. The finding was not equal as previous indication for the Malaysia firms which is heavily run based on family business (La Porta, De-Silanes and Shleifer, 1999 and Claessens, Djankov and Lang, 2000). Further means value for ownership in all types of firms were slightly equal with family-founding firms enjoy more healthy firm performance, while their counterparts report negative to their return of assets. Testing on demographic features for executive age which is commonly applied in many studies to determine turnover events and the findings explain that on average, Malaysian executives decide to vacate their position at the age of 54 years old. This shows that executive turnover rate is far below normal retirement age is 70 years old. And the result reveals there is no significant difference in turnover age between family and non-family domination members as the means value are 54. This result supports with studies conducted in the U.S. which indicate the mandatory retirement age for American CEOs to be 55 years old (Coughlan and Schmidt, 1985; Goyal and Park,2002; Edeme, 2017). And examination on the total compensation pay structures, showing that other than cash payment, equity based payment in the form of stock options plan has made up the second biggest component of remuneration for awarding incentive at the executives' level. Similar evidence was observed across the sub-sample groups. Perhaps, the equity compensation plan is more appropriate mechanism for retaining top executive for at least three to five years until the vesting period ends. This is slightly consistent to Kang (2002), where there is a provision in the company's constitution that are allowed for performance evaluation by the shareholders. This appraisal is a basis for determining at least one -third of board members to be retired in every three years.

Table 2. Summary statistics for all variables

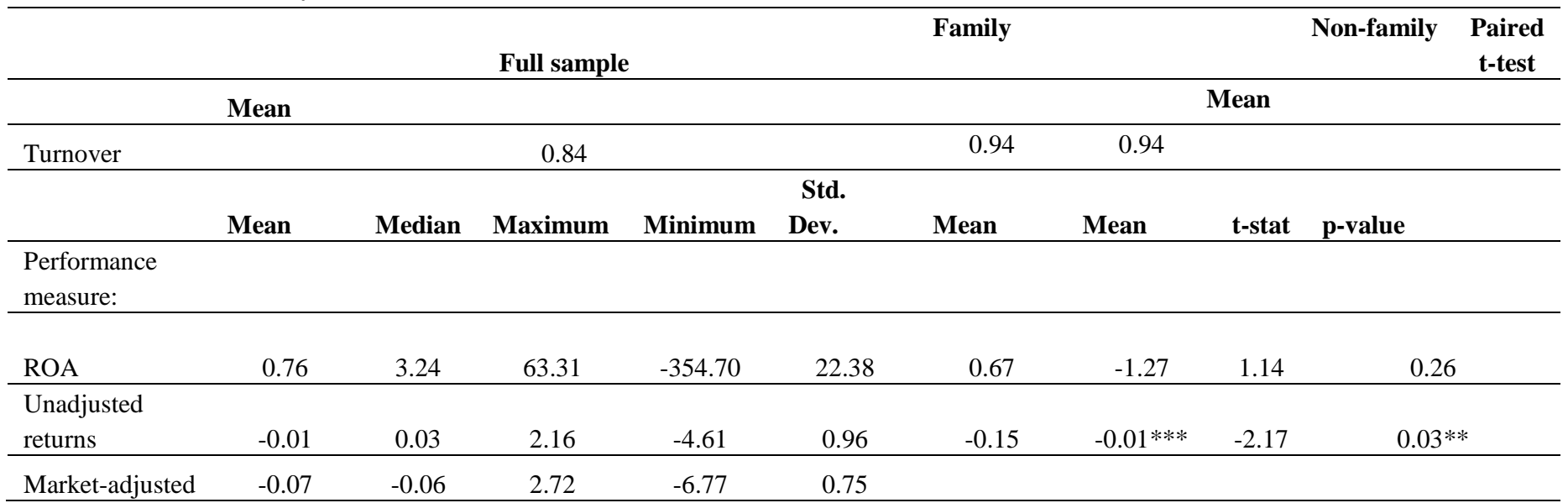




\begin{tabular}{|c|c|c|c|c|c|c|c|c|c|}
\hline returns & & & & & & -0.13 & -0.07 & -1.17 & 0.24 \\
\hline Loss & 0.26 & 0.00 & 1.00 & 0.00 & 0.44 & 0.23 & 0.27 & -1.49 & 0.14 \\
\hline Ownership & 0.03 & 0.00 & 4.88 & 0.00 & 0.22 & 0.03 & 0.03 & -0.09 & 0.93 \\
\hline Age & 53.78 & 54 & 89 & 23 & 10.68 & 53.77 & 54.19 & -0.56 & 0.57 \\
\hline $\begin{array}{l}\text { Equity -basec } \\
\text { plan } \\
\text { [unit] }\end{array}$ & $1,117,457$ & 0.00 & $36,521,650$ & 0.00 & $3,822,105$ & $1,575,198$ & $1,301,772$ & 1.09 & 0.28 \\
\hline Salary (RM) & $1,839,191$ & 955,638 & $68,851,000$ & 43,776 & $4,365,570$ & $2,193,576$ & $1,638,679$ & 1.86 & 0.06 \\
\hline Bonus (RM) & 710,105 & 203,000 & $41,469,000$ & 2,000 & $2,582,184$ & $747,768.10$ & $827,462.20$ & 0.07 & 0.95 \\
\hline
\end{tabular}

For the purpose of the study examination whether there is a difference in result for executive turnover between family and non-family business firms, Abidin (2006) also suggests for several indicators in terms of selecting the matched firms which were on the market listing, industry representations and firm size. In this study, the match for firm size between family and non-family controlled would be acceptable if it falls within the range of 30 percent upper and lower limits. The means value indicate no significant difference between the firm-controlled types. The difference of mean value could be traced for cash plan under the compensation plan structure in which the values are all significant. For top executive age as indicated earlier for Malaysia executives that served as company's director are required to retire when they were reaching the age of 70 years old. Suggested by Weisbach (1988) is to exclude executive turnover around the retirement age from sample selection as it treated as a routine turnover. However, the result uses the Malaysia executive data and reveals a high presence of early retirement cases which is below the compulsory retirement age. For example, there are $79 \%$ of executives that have been replaced below the retirement age and there are cases of $21 \%$ above 70 years old. This denotes that more events in regard if Malaysia executive turnover are classified as forced replacement. Following similar approach, this study attempts to reclassify each case of executive turnover whether it should be classified as a part of forced turnover or routine turnover. For both types of turnover groups, a separate regression model was conducted to examine the turnover-performance effects.

For all models with variable of managerial ownership and compensation structure are set to use dummy variable to account for the event of executive turnover managements are replaced during the sample period. The results show that performance indicators for different sample groups based age show a negative performance generates higher turnover cases. The effect is more influenced by current performance as three out of four performance measures are all significant. This confirms the hypothesized statement that firm experiencing low performance leads to increase of turnover cases. For market performance measure, a positive association shows a weak predictor to estimate the likelihood of executive to being replaced. Extended analysis of turnover effects with previous performance, the result finds insignificant value. This is contrary with Boeker and Goodstein (1993) which found that replacement decision will be evaluated according historical assessment rather current year. When compared to finding with Suchard et al. (2001) and Tsai et al. (2006) as both studies concluded for past performance determined executive turnover. Where the event of estimating the turnover effects using accounting and market-based measures and find that accounting measures are the best better predictor than market based return measures (Gibson, 2003). The findings are equal of Warner et al. (1988), Denis and Denis (1995), Denis et al. (1997), Lausten (2002) and Rachpradit, Tang and Khang (2012). When a dummy variable for firms with loss to represent financial distress firm has tendency to replace the top executive, the positive association with current performance implies that the relationship between executive turnover and performance variables used in the study is treated as weak indicator. This is clearly informed that Malaysian executive turnover is less determined based on firm performance which do not consistent with past findings.

Examination on relationship between managerial ownership in a family founding firm with executive turnover may have an inverse relationship (Pergola, 2005). With assumption of high presence of ownership by family members, the probability of turnover is lower. With a positive result reveals the assumptions are not in line which suggesting that managerial ownership is not important factor for turnover prediction. Perhaps, the characteristic of Malaysian corporate environment which is highly concentrated on family-ownership structure which does not greeting for 
turnover as a strong family-ties association. In this context, it less likely to replace top executives as shown with Maury (2006) that noted the family member commitment and loyalty leads to low turnover. Then, to account for the sensitivity of turnover-performance to family-ties variable and the coefficient value is reported a positive. This suggests that executive turnover is remained to be less sensitive if the firm is family-domination types. For result validation of turnover-performance sensitivity and the assumption is on executive replacement is expected to has a weak effect when there is a strong family-ties over the board. The result reported a weak turnover case with strong family-ties to the firm boards. This is against to the finding by of Tsai et al. (2006) as family firm is commonly found to have an effective monitoring to control for firm performance.

Table 3. Estimation for turnover types and firm performance

\begin{tabular}{|c|c|c|c|c|c|c|}
\hline & \multicolumn{2}{|l|}{ Model 1} & \multicolumn{2}{|l|}{ Sub-sample 1} & \multicolumn{2}{|l|}{ Sub-sample 2} \\
\hline & \multicolumn{2}{|c|}{ For all turnover events } & \multicolumn{2}{|c|}{ Exclude forced turnover } & \multicolumn{2}{|c|}{ Include routine turnover } \\
\hline & Current year $(t)$ & Preceding year $(t-1)$ & Current year $(t)$ & Preceding year $(t-1)$ & Current year $(t)$ & Preceding year $(t-1)$ \\
\hline \multirow[t]{2}{*}{$\mathrm{ROA}_{t}$} & $-0.02 * *$ & -0.001 & $-0.02 * *$ & 0.002 & -0.08 & -0.071 \\
\hline & $(0.03)$ & $(0.89)$ & $(0.05)$ & $(0.81)$ & $(0.11)$ & $(0.22)$ \\
\hline \multirow[t]{2}{*}{ Intercept } & 1.70 & 1.66 & 1.82 & 1.78 & 0.24 & 0.322 \\
\hline & $(0.00)$ & $(0.00)$ & $(0.00)$ & $(0.00)$ & $(0.45)$ & $(0.37)$ \\
\hline Number of Observations & 1083 & 1083 & 1029 & 1029 & 55 & 55 \\
\hline Number of turnovers & 909 & 909 & 881 & 881 & 28 & 28 \\
\hline $\mathrm{R}^{2}$ & 0.01 & 0.00002 & 0.0067 & 0.0001 & 0.076 & 0.0213 \\
\hline \multirow[t]{2}{*}{ Unadjusted return } & $-0.21^{* *}$ & -0.12 & $-0.17 *$ & -0.07 & -0.37 & -0.559 \\
\hline & $(0.02)$ & $(0.15)$ & $(0.08)$ & $(0.42)$ & $(0.23)$ & $(0.13)$ \\
\hline \multirow[t]{2}{*}{ Intercept } & 1.66 & 1.67 & 1.79 & 1.79 & 0.15 & 0.215 \\
\hline & $(0.00)$ & $(0.00)$ & $(0.00)$ & $(0.00)$ & $(0.61)$ & $(0.47)$ \\
\hline Number of Observations & 1081 & 1083 & 1027 & 1029 & 55 & 55 \\
\hline Number of turnovers & 907 & 909 & 879 & 881 & 28 & 28 \\
\hline $\mathrm{R}^{2}$ & 0.006 & 0.002 & 0.004 & 0.001 & 0.005 & 0.0317 \\
\hline \multirow[t]{2}{*}{ Market-adjusted return } & 0.17 & 0.02 & $0.19 *$ & 0.02 & 0.20 & -0.393 \\
\hline & $(0.10)$ & $(0.82)$ & $(0.09)$ & $(0.62)$ & $(0,67)$ & $(0.30)$ \\
\hline \multirow[t]{2}{*}{ Intercept } & 1.67 & 1.65 & 1.80 & 1.78 & 0.03 & 0.164 \\
\hline & $(0.00)$ & $(0.00)$ & $(0.00)$ & $(0.00)$ & $(0.92)$ & $(0.58)$ \\
\hline Number of Observations & 1081 & 1083 & 1027 & 1029 & 55 & 55 \\
\hline Number of turnovers & 907 & 909 & 879 & 881 & 28 & 28 \\
\hline $\mathrm{R}^{2}$ & 0.003 & 0.0001 & 0.0033 & 0.0003 & 0.0023 & 0.0142 \\
\hline \multirow[t]{2}{*}{ Loss in operating income } & $0.37 *$ & 0.05 & $0.40^{*}$ & 0.05 & 0.34 & -0.539 \\
\hline & $(0.07)$ & $(0.81)$ & $(0.07)$ & $(0.79)$ & $(0.59)$ & $(0.45)$ \\
\hline \multirow[t]{2}{*}{ Intercept } & 1.57 & 1.64 & 1.69 & 1.77 & -0.05 & 0.134 \\
\hline & $(0.00)$ & $(0.00)$ & $(0.00$ & $(0.00)$ & $(0.87)$ & $(0.66)$ \\
\hline Number of Observations & 1083 & 1083 & 1029 & 1029 & 55 & 55 \\
\hline Number of turnovers & 909 & 909 & 881 & 881 & 28 & 28 \\
\hline $\mathrm{R}^{2}$ & 0.0040 & 0.0001 & 0.004 & 0.0001 & 0.0023 & 0.007670 \\
\hline \multicolumn{7}{|c|}{$\begin{array}{l}\text { Performance measures are represented by Return on assets (ROA), Unadjusted return and market-adjusted return. LOSS is a dummy variable that is equal to } 1 \text { if } \\
\text { the firm has negative operating income. Forced turnover excluded at the age of } 69,70 \text { and } 71 \text { years old and include executive turnover only at the age of } 69,70 \text { and } \\
71 \text { years old. }\end{array}$} \\
\hline & of significance at & $1 \%, 5 \%$ and $10 \%$, res & & & & \\
\hline
\end{tabular}




\section{Concluding Remarks}

Examination on the effect of granting equity based payment to reduce turnover among the Malaysian executives is consistent with the spirit of agency theory. Awarding stakes for executives has its role for retaining of their service in the firm. Based the results analysis, the performance measures produce clear verification that poor performing firms often lead to higher turnover. Nevertheless, for prediction of executive turnover using accounting performance fails to generate evidence that is better than market measures. And, where the event of executive turnover decisions were split according to routine and forced turnover and how it is sensitive to performance, the findings pointed out to that current firm performance has influenced a decision for executive to being replaced. The presence of managerial stakes in the firm did not leading to low turnover rate. This result is in line with conclusions that high family control and ownership showing that turnovers among executives are not welcome. Perhaps the reasons of strong family ties are reluctant to remove inefficient family executives. Also, where the family members are also members of the board, the likelihood to protect from being removed is likely higher. This result supports the presence of management entrenchment activity in a family founding firm. Moreover, executive age plays important roles for turnover decision, as study's finding highlights that older family members are less likely to be substituted by their new and young counterparts. Conceivably, the result suggests for older executives they have more experience in managing business, thus their capability remains valued. Examination the form of executive payments such as salary, bonus and stock option and its turnover effect, it points outs that mix pays provided to executives influence turnover rate as equity plan creates partial incentive to promote of executive retention. This suggests for conclusion that equity pays less prevent for turnover.

\section{References}

Abdul Rahman, R. (2006). Effective Corporate Governance, 1st edition, University Publication Centre (UPENA), Uitm, Shah Alam, Malaysia.

Abidin, S.Z. (2006). Impact of shifts in correlation structure on international portfolio diversification. Investment Management and Financial Innovations, 3(2), 171-196.

Balsam, S., \& Miharjo, S. (2007). The Effect of Equity Compensation on Voluntary Executive Turnover. Journal of Accounting and Economics, 43, 95-119.

Balsam, S., Gifford, R., \& Kim, S. (2007). The effect of stock option grants on voluntary employee turnover. Review of Accounting and Finance, 6(1), 5-14.

Chen, X., Cheng, Q., \& Dai, Z. (2013). Family Ownership and CEO Turnovers. Contemporary Accounting Research, 30(3), 1166. Research Collection School of Accountancy.

Cheung, Y.L., Rau, P.R., \& Stouraitis, A. (2006). Tunnelling, propping and expropriation: evidence from connected party transactions in Hong Kong. Journal of Financial Economics, 82, 343-386.

Claessens, S., Djankov, S., \& Lang, L. (2000). The separation of ownership and control in East Asian corporations. Journal of Financial Economics, 58, 81-112.

Denis, D.J., Denis, D.K., \& Sarin, A. (1997). Ownership structure and top executive turnover. Journal of Financial Economics, 45, 193-221.

Edeme, R.K. (2017). Analysis of the responsiveness of non-oil exports to fiscal and monetary policy actions.

Family-owned businesses outperform their counterparts, by Tan Zhai Yun. The Edge Malaysia dated October 08, 2018. Retrieved from https://www.theedgemarkets.com/article/familyowned-businesses-outperform-their-counterparts

Gibson, M.S. (2003). Is corporate governance ineffective in emerging market?. Journal of Financial and Quantitative Analysis, 38, 231-250.

Gomez E.T. (2004). De-Essentialising Capitalism: Chinese Networks and Family Firms in Malaysia, NIASnytt 3, $8-10$.

Haniffa, R.M., \& Hudaib, M. (2006). Corporate Governance Structure and Performance of Malaysian Listed Companies. Journal of Business Finance and Accounting, 33(7-8), 1034-1062.

Haslindar Ibrahim, \& Fazilah Abdul Samad. (2010). Family business in emerging markets: The case of Malaysia. African Journal of Business Management, 4(13), 2586-2595.

Hussain, H.I., Abidin, I.S.Z., Ali, A., \& Kamarudin, F. (2018). Debt Maturity and Family Related Directors: Evidence from a Developing Market. Polish Journal of Management Studies, 18(2), 118-134. 
Huson, M.R., Parrino, R., \& Starks, L.T. (2001). Internal monitoring mechanisms and CEO turnover: a long term perspective. The Journal of Finance, 56(6), 2265-2297.

Iqbal, Z., \& French, D.W. (2007). Executive share ownership, trading behavior, and corporate control: Evidence from top management turnover during financial. Journal of Economics and Business, 59(4), 298-312.

Kole, S. (1997). The complexity of compensation contracts. Journal of Financial Economics, 43(1), 79-104.

La Porta, R., Lopez-De-Silanes, F., \& Shleifer, A. (1999). Corporate ownership around the world. The Journal of Finance, 54(2), 471-517.

Lausten, M. (2002). CEO turnover, firm performance and corporate governance: Empirical evidence on Danish firms. International Journal of Industrial Organizatin, 20, 319-414.

Lu, W., Reising, J., \& Stohs, M.H. (2007). Managerial Turnover and ESOP Performance. Quarterly Journal of Business \& Economics, 46(1), 3-19.

Malaysia ranks seventh in number of family-owned businesses, says Credit Suisse. By Wong Ee Lin, Theedgemarkets.com dated October 30, 2017. Retrieved from https://www.theedgemarkets.com/article/malaysia-ranks-seventh-number-familyowned-businesses-says-credit-s uisse

Marshal, I. (2017). Product Brand and Customer Loyalty: A Survey of the Nigeria Banking Industry. Journal of Accounting, Business and Finance Research, 1(1), 7-18.

Mohd Sehat, R., \& Abdul Rahman, R. (2005). Ownership of the Firm and Corporate Value, Working Paper, Faculty of Accountancy, Universiti Teknologi MARA, Shah Alam, Selangor.

Mosbah, A., Serief, A.R., \& Kalsom Abd Wahab. (2017). Performance of Family Business in Malaysia. International Journal of Social Sciences Perspectives, 1(1), 20-26.

Mulyani, E., Singh, H., \& Mishra, S. (2016). Dividends, leverage, and family ownership in the emerging Indonesian market. Journal of International Financial Markets, Institutions and Money, 4, 16-29.

Noor Afza Amran, \& Ayoib Che Ahmad. (2013). Effects of Ownership Structure on Malaysian Companies Performance. Asian Journal of Accounting and Governance, 4, 51-60.

Orumwense, J.O. (2017). Implementation of Continuous Auditing for the Public Sector in Nigeria. Journal of Accounting, Business and Finance Research, 1(1), 19-23.

Oyer, P., \& Schaefer, S. (2005). Why do some firms give stock options to all employees?: An empirical examination of alternative theories. Journal of Financial Economics, 76(1), 99-133.

Pergola, T. (2005). Management entrenchment: Can it negate the effectiveness of recently legislated governance reform?. The Journal of American Academy of Business, 2, 177-183.

Prakash, R., \& Garg, P. (2019). Comparative assessment of HDI with Composite Development Index (CDI). Insights into Regional Development, 1(1), 58-76.

Rachpradit, P., Tang, J.C.S., \& Khang, D.B. (2012). CEO turnover and firm performance: evidence from Thailand. Corporate Governance, 12(2), 164-178.

Senam, N., Akpan, U.U., \& Mboho, M. (2017). Freedom of Information Act 2011 and Press Freedom: Challenges and Prospects for Media Practice in Nigeria. International Journal of Emerging Trends in Social Sciences, 1(2), 74-80.

Shen, W., \& Canella, A.A. (2002). Power Dynamics within Top Management and Their Impacts on CEO Dismissal Followed by Inside Succession. The Academy of Management Journal, 45(6), 1195-1206.

Sokół, S., \& Słupińska, S. (2019). Creative management of the advertising form and content. Entrepreneurship and Sustainability Issues, 7(2), 842-86.

Subair, R.E., \& Oriogu, C.D. (2016). Still an Issue: The Use of Electronic Books in University Libraries in Nigeria. American Journal of Social Sciences and Humanities, 1(2), 67-72.

Suchard, J., Singh, M., \& Barr, R. (2001). The Market Effects of CEO Turnover in Australian Firms. Pacific-Basin Finance Journal, 9(1), 1-27.

Tsai, W., Hung, J., Kuo, Y., \& Kuo, L. (2006). CEO Tenure in Taiwanese Family and Nonfamily Firms: An agency Theory Perspective. Family Business Review, 11-28. 
Volpin, P.F. (2002). Governance with Poor Investor Protection: Evidence from Top Executive in Italy. Journal of Financial Economics, 64(1), 61-90.

Warner, J., Watts, R., \& Wruck, K. (1988). Stock prices and top management changes. Journal of Financial Economics, 20(1-2), 461-492.

Wee Y.,G., Mohamed Dahlan Ibrahim, \& Hasliza Abdul-Halim. (2015). Family Business Succession Planning: Unleashing the Key Factors of Business Performance. Asian Academy of Management Journal, 20(2), 103-126.

Zahiruddin, G., \& Fauziah, M.T. (2012). Effective Interest Alignment Mechanism or Tool to Expropriate: A Review of Malaysian ESOS Adoption. Malaysian Management Journal, 16, 59-74.

Zuriadah, I., Nurhanie, M, Emelda, H., \& Dockery, E. (2016). Executive Stock Options and Its Effect on Short-run Corporate Performance. Journal of Contemporary Issues and Thought, 6, 102-114. 